\title{
An Autonomist Marxist Perspective on Productive and Unproductive Academic Labour
}

\author{
Krystian Szadkowski
}

\author{
Adam Mickiewicz University, Poznań, Poland, krysszad@amu.edu.pl
}

\begin{abstract}
This article starts with a diagnosis of the inadequacy of the dispossession theory for the analysis of the relationship between capital involved in academic publishing and academic labour. It assumes that it is necessary to develop a Marxian theory of productive and unproductive labour within the field of higher education. For this purpose, an Autonomist Marxist perspective on productive labour is proposed, to facilitate analysis of the contemporary subsumption of academic labour under capital, and to organise resistance against it. The essence of this approach is rooted in an exposition of the two-sided perspective on Marxist categories of the critique of political economy. It is used here to approximate the concept of directly productive academic labour and to indicate its apparent limitations. The next step is to present a view on the systemic productivity of academic labour. This is the only way to address the issue of truly productive academic work in the Marxian sense, and the obstacles standing in the way to its full implementation, the key to which is the smooth functioning of capitalist measurement exercised within the field of science and higher education.
\end{abstract}

Keywords: capital, productive/unproductive labour, academic labour, higher education, Marx

\section{Introduction}

Although the labour performed within the science and higher education sector has often been a subject of Marxist reflection, there is still no clarity on how best to decisively capture its productive or unproductive character, or grasp the significance of its effects for the processes of the valorisation of capital. This article, focusing on the relationship between systemically-understood academic labour and capital concentrated in large, oligopolistic academic publishing houses, takes on the task of capturing productivity that escapes the limitations of previous analyses. In order to clarify what I have in mind, the following example will be illustrative.

In January 2012, the British mathematician Timothy Gowers announced his decision to boycott academic journals owned by Elsevier. This is how "The Cost of Knowledge" page (Neylon 2012) came to be created. The reasons for abstaining from publishing, reviewing or editing publications from academic journals issued by Elsevier were explained on this page, and signatures were collected under the declaration. Objections were raised because of the prohibitive prices for access to publications and the huge profits generated by commercial publishers based on the unpaid work of academics all over the world. Within a few months, thousands of academics, mainly representatives of the world of mathematics and science, joined the protest, and the target, Elsevier, not only felt the effects of this boycott directly ${ }^{1}$ but also took a number of steps aimed at alleviating the agitation of these academics. ${ }^{2}$ Although the issue

${ }^{1}$ Using its expertise, Bank Exane Paribas indicated the direct financial consequences that Reed-Elsevier suffered immediately after the boycott's inauguration (Storbeck 2012).

${ }^{2}$ In a series of open letters to the community of mathematicians, Elsevier mentioned its consistent activities aimed at reducing the costs of publishing and helping the global community 
received a great deal of attention and numerous comments, the initial manifesto itself can serve as a lens that brings a clear focus to the issue that concerns subsequent parts of this article.

The text on the website explains: a) changes that have occurred in the dissemination of knowledge and the role of academic journals in this process; b) the near-irreplaceable function performed by the journals in the process of valuating academic achievements; $c$ ) the role of Elsevier in the crisis itself; $d$ ) the reasons for the boycott; and e) the horizon of further actions aimed at introducing a new model of academic communication. In each of these elements abuses were described: either perpetrated directly by Elsevier or as a consequence of the anachronistic solutions offered by the publisher.

The image of scientific production outlined in this manifesto emphasises the importance of the unpaid labour of academics contributed at every stage of the process, as well as how the same academic clientele are necessary for the generation of profits by the publishing houses. In other words, academics paid from public funds produce the initial product, process it independently, and perform the function of reviewers of submitted works; and then the same institutions that employ these academics pay for the possibility of accessing the results of research previously funded from the public purse. The critical stimulus affecting the willingness of higher education employees to work for free on behalf of the capitalist publisher has been identified as the increasingly important role played by the journals published by these publishers in national and institutional evaluation procedures.

Although the central reference in this manifesto pertains to the field of mathematics, the general characteristics of the problems faced by academic workers in their relations with the publishers of academic journals can be extrapolated to other disciplines. The resistance of academic labour was triggered by the lack of a rational answer to the question: why - given the systematically falling costs associated with the production and dissemination of articles, and considering the heavy reliance on unpaid labour at all stages of production - are the prices for individual items and subscription packages so disproportionately high? They are comparable in their irrationality only to the profits gained by these publishers. ${ }^{3}$ The signatories emphasise this irrational asymmetry, writing: "Elsevier, Springer, and some other commercial publishers [...] all exploit our volunteer labour to extract enormous profits from the academic community. They supply some value in the process, but nothing like enough to justify their prices" (Neylon 2012).

In the section of the manifesto quoted above, the presented conflict brings to mind the antagonism between labour and capital. However, the reality of the situation does not allow us to discuss it in terms of exploitation in the proper Marxian sense. On the one hand, although academic workers (most often employed in public institutions) are indeed robbed of the results of their work, they also contribute regularly and voluntarily

of mathematicians to develop their discipline (by funding awards, scholarships or extending free access to classic works). https://www.elsevier.com/physical-sciences/mathematics/open-letters-to-the-mathematics-community

3 It is estimated that the market for academic publishing is worth about 10 billion dollars per annum (Ware and Mabe 2015). The profitability of this venture can be approximated, indicating the level of operating margins generated by the largest publishers. Christian Fuchs and Marisol Sandoval (2013) calculated the "rate of profit" index based on the financial data of selected academic publishers for the financial year 2012 (for Springer 2011). On average, it was $18.2 \%$. Reed-Elsevier $21.7 \%$; Springer $20.2 \%$; Taylor \& Francis $24.9 \%$; Wiley-Blackwell 12.4\%; Wolters Kluwer 15.2\% (Fuchs and Sandoval 2013, 429). 
not only to accumulation but also the valorisation of capital by the large publishing houses, so in this context describing this process as accumulation by dispossession or alienation is somewhat problematic (Peekhaus 2012). We are dealing here with the process of permanent, cyclical expropriation - in this way, the process itself resembles the relation of exploitation, i.e. regular robbery of surplus labour without paying the equivalent due. The resource that is 'expropriated' (knowledge closed in the proprietary form of the commodity-article) is reproduced, and the situation constantly renews. Most employees submit to this procedure 'voluntarily' (having no other option - often being forced by rigid procedures of national or institutional evaluation). On the other hand, they cannot easily be attributed with the status of productive labourers, at least not in terms of the vulgarly-understood theory of productive and unproductive labour, according to which productive labour is the labour performed within a wage-labour relationship, in a strictly capitalist enterprise involving the production of goods for profit.

My starting point here is the tension, outlined above, between the insufficiency of the theory of alienation or dispossession for the analysis of the permanent relationship between capital and academic labour in the context of academic publishing, and the need to develop Marx's theory of productive and unproductive labour in such a way that it precisely captures the relationship between capital and academic labour within the field of higher education. Thus, I will offer an Autonomist Marxist view of productive academic labour to develop a Marxist theory, as well as contribute to the analysis of the contemporary subsumption of academic labour under capital (Hall 2018; Szadkowski 2016a). This effort may potentially increase the capacity for the joint mobilisation of academic staff with other parts of the working class that rebel against the imposition of productivity on their labour by capital (Allmer 2017).

The specificity of the contribution that this article is aiming to make can also be read in the context of the recent discussion held in triple $C$ between Michael Hardt and Antonio Negri (2018a; 2018b) and David Harvey (2018) regarding the relationship between universal alienation and real subsumption. This discussion reveals a broader problem discussed within contemporary Marxist theory. As Christian Fuchs (2018) rightly pointed out, one of the stakes of this debate is an answer to the question of how the structures of exploitation are organised in modern capitalism. One such answer implies that the dominant form of draining surplus from labour takes the form of "original" and "ongoing" primitive accumulation, analogous to the formal and real subsumption of labour under capital (Fuchs 2018, 464). Although the great value of this debate is the agreement reached by the aforementioned theoreticians regarding the basic issues, the tensions that arise both between and within the readings they propose allow light to be shed on the theoretical stake of this article. Using a pair of notions of subsumption, on the one hand Hardt and Negri highlight the problematic nature of the diachronic reading (subsumption as a historical stage of capitalist development; see Vercellone 2007), thereby placing the emphasis on the synchronous reading of labour subsumption under capital; that is, the coexistence of different ways of subordination in different areas and production sectors $(2018 \mathrm{~b}, 442)$. On the other hand, when the authors indicate almost identical similarities between the state of universal alienation and real subsumption, they use the diachronic understanding criticised previously - real subsumption as a specific phase in which contemporary capitalism is located (2018b, 417). Finally, when they discuss accumulation through dispossession, Hardt and Negri emphasise that the mechanism of real subsumption is similar, "but only in part" $(2018 b, 418)$. Real subsumption, as a mechanism enabling the extraction of the jointly produced wealth, is only partly similar due to the fact that, according to the authors, it also assumes the installation of a specific 'rationality' 
responsible for maintaining and enabling reproduction of the expropriation process. In turn, David Harvey rightly expresses doubts about the synchronous reading of the real subsumptions present in the Hardt and Negri's piece, indicating that "we have to be much more explicit about what it is that is being subsumed into what" (Harvey 2018, 450) when discussing the transformations which, as a result of penetration by a specific type of capital (e.g. financial capital in the area of real estate), specific areas undergo (e.g. the area of housing). It is in this context that I would like to clarify the specific understanding of the subsumption of academic labour under capital that I deploy in this article.

As has been presented elsewhere (Szadkowski 2016a), the concept of subsumption should be used for an analysis of the dynamically changing landscape of capitalist production. It allows us to grasp the development and dissemination of capitalist relations based on the form of wage labour and the form of value in the various sectors of human activity. When we refer back to Marx, especially to his Results of the Direct Production Process (1982/1867), we can distinguish four different types of subsumption of labour (formal, real, ideal, hybrid) that coexist synchronically, and, as Marx put it in the third volume of Das Kapital, capital always has to choose in which way it approaches (subsumes) labour in a given sector. It depends on "the solidity and inner articulation" (Marx 1981/1894, 449) of the given mode of production - the more rigid and inflexible it is initially, the further capital strays from its inner logic of the organisation of the direct production processes. However, this does not mean it is not trying to interfere. As Hardt and Negri claim (2018a; 2018b), nowadays we are facing a situation where capital is becoming more and more distanced from the direct form of producing wealth. At times, it resembles the pure process of extraction. This is, according to the American-Italian duo, the moment when the process of capital's domination over labour (real subsumption) comes close ("but only in part" (2018b, 418)) to the logic of dispossession. What differs is the necessity of installation of a certain 'rationality' that fuels the process itself and renews it on a constant basis. The workers of a given sector whose labour was subsumed under capital are not actively dispossessed of the products of their labour to become passive objects of the process. Instead, they are operating within a certain rationality that somehow helps to lure them to participate in this constantly renewed process. This is a difference between extraction and exploitation that I would like to shed more light on in this article, in the context of academic labour and its relationship with large oligopolistic academic publishers. In order to be able to achieve this, I need to reformulate the Marxian conceptual pair of productive and unproductive labour.

This article consists of seven more sections. The second presents the general problem that this article wants to address. The third section briefly reviews Marxist literature on productive/unproductive labour; I present and discuss economic and political interpretations and introduce the Autonomist perspective. In the fourth section, I indicate the actuality of the dynamic and historical Marxian understanding of productive/unproductive labour. I argue that this distinction is still able to equip us with tools for understanding the changing realities of capitalist production, including within the higher education sector. The fifth section outlines a two-sided understanding of the distinction, presenting productive/unproductive labour from both the perspective of capital and that of the working class. The sixth section contains a concise critique of the direct understanding of the productivity of academic labour, opening the way for the considerations in the seventh section on the system-wide, social productivity of academic labour. The eighth and final section contains conclusions and steers the discussion to the communist productivity of academic labour. Before I move on to the 
following sections, I will outline more clearly the most critical problem node to which I want to deliver a solution.

\section{The Problem}

When we look at contemporary academic labour, reducing it to just the dimension of research-related activities, a triple problem emerges. First of all, the autonomous basis of its existence and development are peculiar communication practices (Clark 2006). Academics conduct research and communicate their results in order to reach a specific group of specialists or the broadest possible audience. Furthermore, academic labour in this context seems to be rewarded mainly with something other than just financial currency, namely academic prestige; recognition by the community of scholars (Blackmore and Kandiko 2011; Bourdieu 1984). It is true that academics often or nearly always need support from public institutions, sometimes relying on other sources of income or help from patrons, families or social networks. Having the basic needs and costs of their activity met (access to books and articles, research equipment, unrestricted opportunities to exchange ideas, freedom of movement and participation in conferences, etc.), they can engage in the production and dissemination of knowledge without claiming additional remuneration for their labour outputs. This idealised vision of scientific communication practice is, of course, only a part of a more complex picture.

Secondly, since the end of the nineteenth century, efforts have been made to capture and quantify extremely heterogeneous forms of scientific communication, not only to control them (Godin 2007), but also to exercise constant supervision over their development, growth and effectiveness. Furthermore, these efforts have overlapped with the growing role of the state in the regulation and supervision of science and higher education systems (Neave 2012) and the growth of the importance of scientific communication practices in the organisation of science and higher education systems at the national level. However, the crucial moment in intensifying the efforts to increase the research productivity of academic employees was the moment of establishing the first global university ranking in 2003 (Hazelkorn 2011). This event contributed on an unprecedented scale to the promotion of competition between and within higher education institutions (Shore and Wright 2015), as well as to the general acceleration of academic labour (Vostal 2016). The role of the metricisation of academic labour in this process was crucial.

Thirdly, we are dealing with the intertwined acceleration of capital accumulation by large academic publishing companies, which as a result of a dynamic consolidation process have grown to the position of stable oligopolies (Larivière et al. 2015). The process is accompanied by the strengthening of the position of various suppliers of metrics for measuring and evaluating scientific publications (Wilsdon et al. 2015). Elsevier combines both functions: on the one hand, as an academic publisher offering a wide range of academic journals; on the other hand, running a database of such journals, indexing their interlinked citations outputs (Scopus) and providing metrics, indicators and metadata for its own products, as well as being a general data supplier of global rankings or implementers of evaluation practices. It seems that in its relationship with global academic labour Elsevier is one of the most important beneficiaries of competition, having been transformed from a struggle to extend the frontiers of human cognition, which was taking place between individual researchers and research teams, into a competition between universities or entire countries. This competition is now more concerned with the position in a peculiar "academic arms race" (Münch 2014) instrumentalised by particular capitalist companies. 
The three threads above are intertwined into one problem node of the mutual relationship between academic labour (understood narrowly, exclusively within its research and publishing activity) and capital, which can be captured more lucidly in Marx's categories of productive/unproductive labour.

\section{The Marxist Debate on Productive/Unproductive Labour}

The ability to differentiate between productive/unproductive labour lies at the foundation of a well-functioning capitalist economy. Karl Marx knew this perfectly well and addressed the issue several times, initially in his economic manuscripts (Marx 1973/1939; 1994/1859; 2000/1977), which were supposed to form the basis of Das Kapital.

The discussion on the essence of the distinction has lasted for years (Rubin 1990; Gough 1972; Meiksins 1981), and it has not lost its importance (Duménil and Lévy 2011; Negri 2014; Roberts 2014; Pitts 2015; Ratajczak 2015; Moraitis and Copley 2017). It is as if a statement on the functionality or obsolescence of this pair were a fundamental task for every continuator of Marx's oeuvre who wanted to say something about labour and production under capitalism. In this discussion, the tone adopted is that of strategic economic interpretations conducted from the perspective of capital (Cleaver 2000, 29-31). Such analyses, above all, follow categories and divisions in reference to the functioning of the capitalist economy; ultimately, their aim is to present a picture of the productive/unproductive labour that would save Marx's theory of value from crushing criticism (Savran and Tonak 1999, 133; 147, or especially the threedimensional topological approach presented in Roberts 2014, 339). However, some scholars assume that all workers employed by capital generate surplus value (Houston 1997; Laibman 1999). Thus the pair itself brings nothing analytically relevant to the table.

On the other hand, it also finds fierce defenders (Mohun 1996; 2002). Mohun (1996) reasonably states that when it is devoid of this distinction Marx's conceptual apparatus loses its analytical utility altogether: hence the task facing every Marxist political economist is a systematic rejection of allegations that the distinction is supported on a metaphysical basis. Some, however, rightly point out that Marx's concepts are not burdened metaphysically, but that capital as the source of all transcendence within the field of production is not able to ground the productivity of labour other than by determining metaphysically what is productive and unproductive (Ratajczak 2015, 97).

The second significant stream in this ongoing discussion is political interpretation. The authors following this current take as their aim the development of such formulation of the productive/unproductive labour dichotomy that would allow for the expansion of the class struggle. If productive workers play an essential role in effective resistance to capitalism, then proving that all labour has or can have a productive character for capital allows the struggle to be opened up against it to the broadest possible group (Lebowitz 2003; Harvie 2006; 2005; Negri 2014). An example of such an extension of the category of productive labour is David Harvie's (2006) inclusion of teachers (including academic teachers) employed in the public sector. Harvie claims that his intention is not to be in logical compliance with Marx's writings. This seems to be impossible. He instead believes that his perspective is much more useful in understanding the processes in which teachers produce and reproduce capitalist social relations, and points to the potential of teachers to break this (re)production. According to Harvie (2006), teachers are productive labourers, as long as they are subjected to alienation, and exposed to the capitalist measuring of their labour. Another approach has been developed by Michael A. Lebowitz, who argues that economic discussions 
devoted to the conceptual pair point to the far-reaching one-sidedness of these Marxist readings $(2003,133-136)$. The fetish of the objectivist capturing of capitalist processes obscures the political dimension of Marxian categories, as if Marx was developing the political economy of capitalism, not its critique. Labour can also be productive and unproductive for workers' needs - opening perspectives for their development. Thus, these approaches indicate the two-sidedness and political nature of the productive/unproductive labour categories.

Marxists of an Autonomist orientation are most often located in the political current. With their approach questioning the majority of fundamental Marxian distinctions and concepts, they ignite widespread doubts and controversies. The most-criticised author of this stream is Antonio Negri (Caffentzis 2005; De Angelis 2005; Kicillof and Starosta 2007), who in the 1970s rejected this distinction as obsolete and only used by those who want to spice up Marx with old nineteenth-century materialism (Negri 2014). However, some Autonomist intuitions seem to describe much better than is indicated by the scathing criticism of their opponents the way the relationships between labour and capital are shaped, and what difficulties capital encounters (and how it overcomes them) in trying to impose labour productivity on some sectors of the economy. I believe that following the two paths determined by the intuitions of the Autonomists, that is, following their insights into the transformation of production (Pasquinelli 2009; 2014a; 2015), as well as being faithful to their political stance (Negri 2014; Harvie 2005), makes it more sensible to capture today's changes in the higher education sector. I will develop both of these threads in subsequent sections of this text.

\section{Marx and Productive/Unproductive Labour}

Marx approached productive/unproductive labour in the first volume of Theories of Surplus Value, where, referring to the findings of the classics of political economy (mainly Adam Smith), he identified the three basic definitions of productive labour within capitalism. Therefore, according to Marx, productive labour is that which: a) is exchanged for capital $(2000 / 1977,144)$; b) is realised in the commodity form (2000/1977, 149); and c) creates surplus value (2000/1977, 144; 323). The terms a) and b) were taken (with modifications) from Smith. Moreover, the former makes the productivity dependent only on the relationship of labour with capital (regardless of its material form), while the second emphasises the importance of the commodity form of labour outputs. The third term had a special meaning for Marx because it places productive labour at the centre of his theory of value, and thus also at the basis of his political project.

According to Marx, each productive worker is a wage labourer, but not every wagelabourer is productive. The author of Capital points out that a considerable number of activities and functions that until that time had been considered ends in themselves were transformed due to the development of capitalist production, becoming turned into wage labour regime-related activities. Their value began to be estimated and measured according to the principles of wage labour valuation. However, the mere commodification of a given activity is not a sufficient condition for it be treated as productive. This is why the two modes of labour are often confused with each other in order for labour to be productive, it is necessary for a given activity to be included in the process of producing surplus value as a living factor.

The living factor of production becomes socialised. As Marx wrote in Capital: "The concept of a productive worker therefore implies not merely a relation between the activity of work and its useful effect, between the worker and the product of his work, but also a specifically social relation of production, a relation with a historical origin 
which stamps the worker as capital's direct means of valorization" (Marx 1982/1867, 644). Therefore, the productive worker for capital is primarily a means of creating surplus value, which is the essence of capital - its beginning, its constant desire and the object of its infinite lust. The social relation between labour and capital is the relation of productivity.

The case is different with unproductive labour. Marx's indications may seem somewhat arbitrary, as he lists three types of labour as unproductive: first, labour that results in the mere reproduction of the labour force $(2000 / 1977,144)$. Without this arbitrary exclusion, not only would the analytical framework allowing for the capture of the production of surplus value collapse, but above all the basis of the capitalist economy would be shaken up. The second type of unproductive labour is supervision over the labour of others (e.g. controlling employees who work independently) (2000/1977, 1140), distinguished by Marx from labour related to the organisation of labour of others - i.e. providing cooperation schemes (1981/1894, 383). The third type of unproductive activities are those involved in circulation (Marx 1973/1939, 120). Here, too, Marx makes an arbitrary exclusion: transport and everything related to it is considered a productive activity.

Unproductive labour is, therefore, an activity that, despite being conducted in the form of wage labour, is exchanged for income or revenue $(2000 / 1977,147)$, i.e. one that does not contribute to the direct production of value. In the case of unproductive labour, a kind of law of value operates. The value of services is determined by socially necessary labour time, as well as being dependent on the cost of its reproduction. Unproductive labourers may also perform surplus labour.

Finally, the matter gets even more complex when we add to the above picture the problem of the gradual expansion of the concept and phenomenon of the productivity of labour, which accompanies increasingly complicated capitalist production. In both Grundrisse and Capital, Marx highlights the insufficiency of the direct understanding of productive labour. He connects the expanding scale of cooperation in capitalism with the modification of the productive nature of labour, asserting that: "With the progressive accentuation of the cooperative character of the labour process, there necessarily occurs a progressive extension of the concept of productive labour". The condition to be productive becomes "to be an organ of the collective labourer, and to perform any one of its subordinate functions" (Marx 2000/1977, 643-644). Capitalist productivity, with an appropriate degree of social development of production, spills over the entire factory (and, as Italian Autonomists of the operaismo stream showed in the 1960s, onto the whole social fabric).

\subsection{The Historical and Political Determination of Productive and Unproductive Labour}

Marx's division into productive and unproductive labour is therefore formal and dynamic. It depends on the network of social relations in which the activity is involved. As Isaac Rubin points out, Marx, while relying on his method consistently, "throws out as useless the question of what kind of labour is productive in general, in all historical epochs, independently of the given social relation" (1990, 260). His intuitions, which were so clearly laid out at the beginning of the chapter on the labour process and the process of the valorisation of capital in the first volume of Capital (Marx 1981/1894), were well interpreted by Bruno Gulli (2005), who claimed that the category of labour developed by the political economy of the capitalist mode of production does not correspond to what labour is as a concept. Labour is productive or unproductive, but as he points out - for capital, and only when it operates within its framework. Gulli introduces the notion of neither-productive-nor-unproductive labour - or neither/nor 
labour - in its neutrality, to reflect what, for Marx, exists on the ontological level. The determination of a given activity within this opposition always takes place in specific historical conditions of production.

From the assumption of the initial neutral status of labour, we can draw a necessary consequence. As Marx put it in Theories of Surplus Labour: "The same kind of labour may be productive or unproductive" $(2000 / 1977,326)$. It is a concrete relationship in which the given labour is performed for capital that determines its status: "What forms its specific use value for capital is [...] its character as the element which creates exchange-value, abstract labour" (2000/1977, 326). Looking at this problem from the perspective outlined above, we can see Marx's intentions, as he meant that "this distinction expresses precisely the specific form of the labour on which the whole capitalist mode of production and capital itself is based" (2000/1977, 323); more specifically, the totality of social relations in which a given activity and its subject is located - which generates surplus value for capital. When the hegemonic form of extracting surplus value from labour gets transformed (e.g. as a result of "becoming a rent of profit" (Vercellone 2007)), and the relationship between labour and capital changes accordingly, the form of imposition of productivity on labour also gets transformed.

It is in this Marxian approach to productive/unproductive labour, which on the one hand assumes that this conceptual pair is crucial to understanding the actually functioning capitalist mode of production and, on the other, that the range of its functioning is determined continuously by relations between classes, I would like to embed further considerations that form the core of this article.

\section{The Two-sided Perspective on Productive/Unproductive Labour}

There is a fundamental duality inscribed in the essence of political economy, which Rosa Luxemburg perceptively indicated more than a hundred years ago. As she wrote: "At the very first step across the threshold of political-economic knowledge, with the first fundamental question as to what political economy is and what its basic problem is, the paths of bourgeois and proletarian knowledge already diverge" (2013/1925, 132). While the former field uses the grid of its categories to hide the anarchy of capitalist production, the latter uses them to expose it, and ultimately to build on its ruins a system that enables the realisation of the continually expanding needs of the working class. These two perspectives, although overlapping in the area of analysis of capitalist relations (one of them somehow builds on the achievements of the other), are disproportionate, and ultimately antagonistic.

It is no different for the basic categories of political economy, including the conceptual pair of productive/unproductive labour that interests us here. As Marx wrote: "It is only bourgeois obtuseness that encourages the view that capitalist production is production in its absolute form, the unique form of production as prescribed by nature. Moreover, only the bourgeoisie can confuse the questions: what is productive labour? and what is a productive worker from the standpoint of capitalism? with the question: what is productive labour as such?" (1981/1894, 1040). The naturalisation of capitalist reality, which goes hand in hand with the absolutisation of the categories used to describe it, is not only something ruthlessly attacked by Marx (1973/1939, 81-115), but also something always deliberately addressed when it comes to transplanting these categories to his discourse. Therefore, several times he points to this fission, as in the Theories of Surplus Value, where he claims that the actual productivity of labour involves the necessity of abolishing the foundations of producing surplus value and transferring the created surplus to the workers. As Marx wrote: 
"Assuming, however, that no capital exists, but that the worker appropriates his surplus-labour himself - the excess of values that he has created over the values that he consumes. Then one could say only of this labour that it is truly productive, that is, that it creates new values" $(2000 / 1977,145)$. Thus, the quoted fragments show not only the ontological neutrality of labour ('labour in general') but also the possibility of having at least two opposing modes of productivity: productivity for capital and productivity for the worker.

The abovementioned duality is a starting point for formulating contemporary perspectives on productive/unproductive labour. A good example is David Harvie (2005), according to whom this distinction must be treated as a category of struggle, not as a category of the movement of capital. Capital continually strives to make every activity productive labour. Conversely, the working class should strive (and is striving) to make as many activities as possible unproductive labour (that is, unproductive for capital). According to Harvie, the struggle against manifestations of the functioning of the law of value, against the imposition of a social measure on the new areas of human (and non-human) activities, is the essence of the struggle against productive labour $(2005,30)$. The processes of the self-valorisation of the working class ${ }^{4}$, that is, the positive and autonomous formation of the means of subsistence and expansion of living labour, are unproductive from the perspective of capital, yet they are the axis of building communism.

This vision is further developed by Michael Lebowitz (2003) and Negri (2014). Lebowitz made a valid attempt at the philological development of the concept of twosided Marxism, indicating at the same time that the Smithian concept of productive labour developed by Marx is just one-sided - coined from the perspective of capital. Supporting one-sided Marxism not only exposes the proponent to easy criticism, but also poses no challenge for capital. Productive labour for a worker is labour that produces useful values for workers, the labour involved in reproduction, and activities that are conducive to the development of human and non-human beings in general. Productive labour in this sense is, therefore, only that which rebels against exploitation in the movement of self-valorisation of workers' social labour - the collective force that produces the common. ${ }^{5}$

As we have already stated, Marx emphasised the inadequacy of the concept of direct labour for defining productivity at a particular stage of the development of capitalist production and cooperation developed on a social scale. It is a starting point for Negri's interpretation of the concept of truly productive labour as a constituent

${ }^{4}$ The concept of self-valorisation of the working-class comes from Italian autovalorizzazione di classe operaia, a term coined within the Italian Marxist current called operaismo, in order to grasp the autonomous processes of development and the creation of wealth against and beyond the rule of capital. At first glance, drawing on Marxian vocabulary dedicated to the description of the movement of capital may seem misleading. However, in the English translation tradition, it aimed at even clearer expression of the two-sidedness inscribed in the Marxian perspective that I refer to in this article.

${ }^{5}$ Indicating the horizon of an alternative to capitalism with the use of the concept of self-valorisation may suggest founding this vision of the future on the category of value, which is only a form that wealth takes under capitalism. To avoid this kind of misunderstanding, Autonomist Marxists like Michael Hardt and Antonio Negri (2009) developed the concept of the common - an alternative form of wealth that communism is based upon. The process of working classes' self-valorisation may for this reason be expressed as a process of multiplication of the common. However, for the sake of conceptual clarity, in building my argument I use the smallest number of different concepts possible. 
power. Although the Italian Marxist states that it is in Capital where "the concept of direct productive labour is ultimately inscribed in the concept of social productive labour" (Negri 2014, 205), his main point of reference is the vision sketched by Marx in the so-called "Fragment on Machines" (1973/1939), where the conflict between the time spent on production and the disposable time for workers' own development was inscribed into the general dynamics of technological development in capitalism and attached to the importance of scientific production. The axis on which this conflict is taking place is the gradually decreasing share of direct labour needed in the production of value as opposed to the growing importance of the productivity of social relations in their totality.

The tendency to increase our collective forces and the resources that allow us to enjoy their effects in the conditions of social harmony is in a way embedded in the dynamics of capitalist development. The mere breakdown of the basis of measure (direct labour measured by time) does not automatically constitute an open gate to the new balance of power in the capitalist economy - it does not entail its automatic crash. Unlike Negri, I believe that capital is very efficient at finding new ways of measuring social labour. However, with the development of the process observed by Marx, the socially-perceived scale of the irrationality of applying these measures to the social reality of production is growing.

However, this does not change the fact that Negri accurately described the nature of productive labour under the new conditions: "as a whole, the exploited social labour that opposes (and is objectively antagonistic) [...] various forms in which capitalism maintains its rule. Then, unlike capitalist power, it is possible to classify productive labour as such collective power that produces the common" $(2014,223)$. In this context, exploitation is becoming more and more often "a form of expropriation of social cooperation, corruption of the common" $(2014,223)$.

I assume that the categories of productive/unproductive labour within capitalist production are characterised by an antagonistic tension. It must be stated not only that the pre-existing productivity of a given activity for the group that performs it is the starting point for the efficient productivity of labour for capital, but also that the material movement underlying capitalist expansion creates conditions for the development of social production on an unprecedented scale. Such pre-existing structure of productivity undermines capital's imposition of mechanisms of measurement, which does not correspond to labour's heterogeneity and the form of wealth it creates; in other words, the common. Unlike Negri or Harvie, however, I see the importance of understanding contemporary mechanisms on the basis of which capital tends to impose productivity on living labour. If capital continually strives to transform and subordinate all kinds of activities and make them productive, we must be aware of the logic of this movement and take it into account when formulating our resistance strategies. Therefore, the two-sided perspective on productive/unproductive labour being consistent with the essence of the proletarian science of the critique of political economy - should be able to grasp capital in its limits, as well as indicate the conditions for the existence of an autonomous community of producers. In the remaining sections of this article, I will look at the productivity of academic labour from this two-sided perspective.

\section{Directly Productive Academic Labour}

There is no single approach to the productive aspect of academic labour. David Harvie believes that the existing balance of class power determines the distinction between productive and unproductive labour in a capitalist society. Every activity has the 
potential to become both productive and unproductive for capital. At present, however, according to Harvie, we are dealing with the subordination of the (higher) education sector to capital, and therefore the work in it is primarily productive (2005). This subordination assumes various types of measures and indicators that operate by reflecting the logic of the law of values within this sector (De Angelis and Harvie 2009; Szadkowski 2016b; Woodcock 2018). Simon Marginson revealed similar tensions in Marx's application of the concept of productive labour, indicating that capital achieves the productivity of the educational services sector, expanding the privatisation and capitalisation of the public institutions of higher education (1998).

Similarly, Bruno Gulli (2009), Stefano Harney and Fred Moten (1998) consider the university sector as the last stronghold defending itself (though less and less) from the progress of real subsumption - through which academic labour is transformed into productive labour for capital. All these positions combine the conviction that capital has a somewhat universalising power and can extend its relations to new areas, regardless of their original specificity. Even if the practice of labour subsumption under capital is accompanied by fierce resistance, the original specificity of the subordinated sector is not assumed to affect how capital functions within it.

This situation tends to distinguish the areas of immaterial production, in particular within science and higher education. The conditions that Marx writes about - for example, the inclusion of academic labour in private and profit-oriented enterprise $(1982 / 1867,1044)$, or employing academic staff on a wage basis, or offering goods in the form of commodities that realise the surplus value through the market - occur relatively rarely within this sector. The core of higher education and science systems are public or private non-profit institutions. This fact was highlighted by Marginson (2016) when he tried to answer the question of why the years of implementing the neoliberal model of higher education and science reforms in the New Public Management paradigm failed to bring about the expected results: above all, why they did not lead to the creation of truly capitalist markets in this sector. On this occasion, he not only accurately described the anatomy of capitalist market relations but also listed the limitations that became apparent in the implementation of the type of reforms based on their logic. He placed an important emphasis on the internal limitations (the nature of knowledge as a public good, and inalienable status competition in the academic field) and external limitations (primarily political, related to the importance that higher education has for national states) that are specific to the sector, and which prevent the implementation of capitalist markets outside narrow 'islands' that strictly focus on profit maximisation.

The problem with this approach, however, is that it ignores all the issues related to the capitalist aspects of the functioning of today's higher education systems, including, in particular, capitalist production taking place within its framework (Hall 2018, 99-100). What is instructive, however, is how Marginson argues against Marxist interpretations of contemporary changes in higher education, when he warns against losing sight of the specificity of the sector of which one is developing a critique (2016, 176-177). In this context, Marginson denounces "the assumption that higher education is, in essence, a variant of the old base-superstructure model bequeathed by Engels" (2016, 176), which is allegedly widespread among Marxist theorists. Such an imaginary and easy-to-tackle opponent resembles a representative of some economic reductionism or even a Stalinist vulgar dialectic materialist, whose only tool of analysis is the base and superstructure model, in which higher education and science fall into either one pole (university-factory) or the other (state ideological apparatus). It is true that in this way the uniqueness of academic labour and its products would be subject to far- 
reaching blurring. The Marxist approach can offer a much more complex analysis than this. The biggest problem with Marginson's reading is his lack of an understanding of the precise mechanism by which capital subsumes academic labour at the level of entire higher education systems, using for this purpose, for example, mechanisms of competition for academic status.

In order to escape the limitations of the perspectives outlined above, it would be necessary, following in the footsteps of Marx and Negri (2014), to enter the reality of the socially-understood productivity of academic labour. An essential step in this direction has been taken by Thomas Allmer (2017; 2018), who, following a similar recognition of the political importance $(2018,54)$ of emphasising the indirect contribution of academic labour to the creation of surplus value $(2017,6)$, developed an elaborate framework for understanding the social embeddedness of academics in the broader relations of production. While Allmer provides a comprehensive and precise picture of what I call elsewhere the ideal subsumption of academic labour under capital within the public university (Szadkowski 2016a), my intention here is much more modest. In the final part of this article, I want to focus on just one dimension of the labour/capital relationship in higher education; that is, on the publication of research results that capital in the academic publishing sector dominates through the establishment of a complex system of measuring academic labour outputs.

\section{Social Productivity of Academic Labour}

The task facing Marxist analysis which would like to establish a proposal for a precise recognition of the dual productivity of academic labour is to indicate how the logic of praxis of a given (academic) field is first instrumentalised (hybrid subsumption), absorbed (formal subsumption), and then processed (real subsumption) by capital (Szadkowski 2016a), creating conditions for its abolition. The key to this undertaking is to examine the tension between the individualising and the abstracting measure developed and imposed by capital and the social basis of academic production (and the measure itself).

I have referred to the measure several times in this text - it would be appropriate to explain what its significance is for the phenomenon that interests us here. Value is socially necessary labour time (Harvey 2010), which is a measure, fixed in capitalist production, under which all work processes are subsumed. The 'measure' and tendency to abstract are inherent in capitalist reality, and the global system of higher education has become an area in which capital places and strengthens its processes of the valorisation and expansion of the creation of surplus value. To permanently establish the domination of measurement processes over a specific area and to identify the activities in it as production, capital must install measurement processes that will drive its movement within a given sector. The capitalist measure in higher education is a process of mapping of social relations established by academic labour. It is a process, as Negri sees it, of "expropriating social cooperation" $(2014,223)$.

De Angelis and Harvie, in their work on the British higher education system, pointed out the systemic way of functioning and the vital issue of the measure in the relations between academic labour and capital. In higher education, the imposition of the procedures of measurement works through two parallel processes (De Angelis and Harvie 2009, 26). On the one hand, there is a diachronic movement, a pressure to reduce socially necessary labour time for the 'production' of ideas and affects as part of both research and teaching. The context for this movement is a policy of making continuous cuts and shrinking public budgets for science and higher education. In this 
diachronic process, one can squeeze more out of academic labour - more texts, more hours spent with students, more patents (Hall 2018).

On the other hand, at the national and global level, there is a synchronous movement, a movement of constant comparison of academic labour, in the context of which heterogeneous activities are subsumed under the form of abstract labour. In the case of research, the measure by which achievements in science are pulled under the common denominator is a bibliometric indicator like the Journal Impact Factor, often translated into the value of individual researchers' achievements within the evaluation processes. In this way, a basis for the functioning of mechanisms estimating the socially necessary labour time in the sector is created. These processes mutually reinforce each other. The constant struggle of capital to impose the 'law of value' is a simultaneous struggle to impose a measure constituting an underlying mechanism that gives roots to the productivity of labour.

In their discussion on the procedures of evaluation of academic labour in a mostly public British system, De Angelis and Harvie are unable to show a direct connection between the practice of measurement and the functioning of capital within this field. Exposure of the measurement procedure alone is enough for them to state that we are dealing with the imposition of the law of value, and thus with the productive labour for capital. The latter, however, remains elusive in this analysis. Carlo Vercellone (2007) rightly points to the constant striving of capital to avoid coagulation in the production process. At each stage of its development, capital must decide on the degree of involvement in the production area. At this point, it must always freeze for a certain period, which is something contrary to its essence. The involvement in the organisation and control of the scientific enterprise is additionally burdened with a significant risk of failure to obtain a quick or even long-term profit (Mazzucato 2013); therefore, it is difficult to imagine the existence of the mass-scale private research institutes that Marx wrote about - especially in the area of basic research. However, capital harnesses various types of mechanisms to enable its valorisation processes.

The basic observation from which one should start a discussion on the social productivity of academic labour is Gigi Roggero's claim that in contemporary capitalism "capital is less and less capable of organising "the top-down « cycle of cooperation" $(2011,71)$. Because it is no longer able to carry out this task, it ceases to be interested in taking control of the direct production process. If we look at the landscape of global higher education, we see that from the perspective of capital, what matters is what appears through the established framework of measurement. All the remaining processes can be freely supported and powered by governments and the state.

In the realities of higher education, capital carries out self-valorisation processes, not so much through the domination over a single institution, but rather through the determination of the conditions for functioning of the global system with its more significant centres (in terms of productivity) and less critical (but essential when it comes to consumption) peripheral systems. As Roggero writes, "the act of accumulation, the interception of value produced in common by living labour/knowledge, is increasingly taking place at the end of the cycle" $(2011,71)$. The same happens in the relationship between the production cycle of publicly funded research and the publishing effect captured by commercial capital involved in academic publishing.

The chief pursuit of capital in this sphere is, therefore, making the heterogeneous products of the human mind countable and comparable. On the one hand, the practices of measurement taking place in higher education extract value from the relations described by them; on the other, they indicate what is directly productive for capital. 
Thus, it is the measure that becomes the foundation of the decision upon the productive/unproductive status of academic labour. We can even say, as Matteo Pasquinelli claims $(2014 a ; 2014 b)$, that capital as such is a process of counting. The companies dealing with the processing of bibliometric data (such as Clarivate Analytics or Elsevier) constitute centres of calculation that work in the service of merchant capital involved in academic publishing, conducting activities focused on profit themselves, and comprising one of its factions.

Pasquinelli, who has long been interested in the mechanisms of transforming the general intellect into a network surplus value, focuses on various algorithms and mechanisms for generating metadata. Pasquinelli (2015) distinguishes two types of information machines and algorithms: a) enabling the translation of information into information; b) enabling the accumulation of information and the extraction of metadata, i.e. information about information. The mechanisms used by Clarivate Analytics in its Web of Science database, and especially in its flagship product, Journal Impact Factor, are algorithms of the latter type.

As Pasquinelli writes, "Metadata is the 'measure' of information, the computation of their social dimension and the potentiality of their transformation into value" $(2011,22)$. One of the three aspects of the functioning of algorithmic machines that generate and accumulate metadata is interesting from our perspective. Pasquinelli writes that "metadata are used to measure the value of social relations. At the first level, the accumulation of information reflects and measures the production of social relations in order to transform them into a commodity value" $(2011,23)$.

The mechanism that may shed some light on the way that such bibliometric indicators function in relation with academic labour is the logic behind Google PageRank, which according to Pasquinelli, is a diagram of cognitive capitalism. In 1998, Sergey Brin and Lawrence Page laid down the foundations for the PageRank algorithm, noting that its fundamental logical matrix was derived from the mechanisms of citation-counting within academic bibliometrics. Google PageRank allows a hierarchy of results to be produced in order to extract the most relevant ones. It is thus able to transform collective knowledge (such as that produced by the citation system) into a proprietary scale of values - in a hierarchy that is then transformed into a proprietary product. PageRank is a "machine for the capture of living time and living labour capable of transforming the general intellect into network value" (Pasquinelli $2009,2)$. A similar way of determining values - as indicated by Pasquinelli - can be applied to any cognitive object: "In the case of both academic publications, as well as commercial brands or internet rankings, equivalent processes of condensation can be assumed" $(2009,5)$.

As part of this algorithm: "the value is determined by both the quantity and the quality of incoming links. In particular, a link coming from a high-ranking node has more value than a link coming from a lower-grade node" (Pasquinelli 2009, 3). In the case of index databases like Web of Science or Scopus, the question of node value is defined as a threshold condition (the very possibility of being included in a given database) - journals that are indexed are determined (through existing references to them in other 'visible' journals) as having 'high rank' - the remaining ones are excluded from the sphere of visibility. In this way, the hierarchy of references is flattened in the database itself.

However, in contrast with Pasquinelli, it should be noted that in the case of academic labour in relation to merchant capital involved in academic publishing and mediated by metadata providers, it is not that the value is captured, but that the measure allows a social and socially-created heterogeneous wealth of relations (the 
common) to be revealed as value. Mechanisms of capture simply allow targeting often with the help of state institutions, as we have seen in the case of state procedures for the evaluation of academic labour, which De Angelis and Harvie (2009) described with reference to the British case (for an updated picture see Woodcock 2018) - of social heterogeneous energy to produce what can be measured and shown as value.

One example is the algorithms that fuel the contemporary global university rankings, which are mechanisms for determining prestige within the field composed of higher education institutions. However, mediation is done on two levels - rankings are a second-degree algorithm. The first is the distribution of citations in specific databases and journal positions calculated on their basis. Within these databases the positioning of academic journals is first made by the activity of individual researchers (not only their contribution in the form of articles, but also bibliographic references used within them); then the data and the results of the comparisons constructed on their basis feed the engines of ranking algorithms. To paraphrase Pasquinelli, one can say that what "impact factor" or SNIF "recognizes, and measures is the network value in its quantitative form" $(2009,6)$.

While Google achieved, through the use of the PageRank algorithm, not only "the dominant position in network indexing, but also a monopoly on the production of this network value" (Pasquinelli 2009), in the field of scientific production and bibliometrics, the struggle for the monopoly is taking place between Clarivate Analytics, with its patented Journal Impact Factor product, and Elsevier, with its various indicators calculated on the basis of data from the Scopus database. However, the importance and the rate of success of each of the private entities is demonstrated by the role they play in the context of data delivery for the global rankings of universities (where the balance is slowly shifting towards the dominance of Elsevier). It is such rankings that focus the attention of legislators, societies or the management of academic institutions around the world, contributing to the intensification of competition between researchers and institutions, and as a result, to even more absolute submission of the research results to journals indexed in these databases. It is in these two contexts (the production of data transformed by database owners into metadata supplying global and national comparisons, and publishing the results of their research work, primarily in commercial journals indexed in these databases) that the productivity of academic labour for capital should be considered today.

\section{Conclusion - Academic Production of the Common}

The starting point of this article was the inadequacy of the theory of alienation and dispossession to explain the relations between academic labour and large oligopolistic academic publications, presented not only in general terms, but also with reference to the example of the Elsevier boycott of 2012 by a global community of mathematicians. The theoretical stake of these considerations was not only to understand the relations of exploitation and subordination of the academic labour sector, but also the conditions of the possibility of renouncing them. These relations were exposed through the prism of the Marxian concept of productive and unproductive labour, grasping not only how capital imposes labour productivity but also how work creates and expands the conditions of its autonomy in the productive self-valorisation movement. The limitations of the direct recognition of the productivity of academic labour have been indicated: such labour, mainly performed at public institutions, rarely fulfils the conditions of directly productive labour as defined by Marx. Finally, the crucial role of measurement processes of academic labour on a systemic social scale has been shown: these not only allow for the channelling of academic efforts on a global scale in specific 
publishing venues controlled by oligopolistic publishers, making them productive for capital, but also shows and accelerates the multiplication of communication links between academic workers.

Voluntary submission to the permanent expropriation of the effects of academic labour, which happens through the realm of academic publishing, is characterised by a permanent relationship that capital establishes through the mediation of a system of measurement. In this sense, one can recognise that a system resulting from a complex set of activities of national governments, bibliometric data providers, commercial and academic publishers and, finally, the creators of global university rankings forms the mechanism of real subsumption of academic labour under capital - such transformation of internal modes of organisation of an academic field not only allows for mapping the relations of productivity within the global system, but also helps to extract the productive energy of academic living labour on a constant basis by capital located in oligopolistic academic publishers. In other words, the mechanism of measuring and comparing the academic labour described above enables permanent enforcement of the channelling of publication efforts in the journals that belong to a small group of academic oligopolistic capitalist publishers (Larivière et al. 2015). At the same time, the measure applied within this relation exposes a specific common space between the broader working class and academic labour scattered all over the world.

Moreover, this system allows not only accelerated communication between researchers, but becomes the foundation of feedback mechanisms on the significance of published results in times of scientific hyper-production. All of this, however, is based on the existing communication practices of the scientific community focused on the production of knowledge as the common.

We have seen above, first with the example of "The Cost of Knowledge", and then in the context of the significance of measurement processes and metadata providers, that not only do everyday practices of academic labour (citation sources, reviewing articles) form the basis of all capital ventures in the field of science, but also that capital valorises the network of relationships created by academic labour through mapping and further interception of the value formed. Therefore, the whole process of scientific communication could potentially take place entirely outside its relationship with capital, in the immanent space of creation of the common - although today, apart from the existing material practices that support this parasitic accumulation, there is not much to suggest this possibility.

Academics do not cease to question this state of affairs collectively, for example, by the publication of the San Francisco Declaration on Research Assessment (DORA) or the Leiden Manifesto (Hicks et al. 2015). Fierce opposition to the misuse of indicators like the Journal Impact Factor used for individual evaluation, and indirectly, against extorting ever-increasing productivity and publishing in specific publication channels belonging to the capitalist giants of the publishing market, and finally the postulate to develop alternative ways of assessing academic work, all supported by thousands of scientists and hundreds of scientific organisations around the world, have not yet resulted in lasting effect, nor have they led individual university authorities or legislators to altogether abandon the use of capitalist measures.

Truly productive Marxian academic labour, that is, the creation of knowledge without the mediation of capital - knowledge that would contribute to the common and shared wealth - seems to require the final abandonment of the measure, or at least some form of its significant modification. 


\section{References}

Allmer, Thomas. 2018. Theorising and Analysing Academic Labour. tripleC: Communication, Capitalism \& Critique. Open Access Journal for a Global Sustainable Information Society 16 (1): 49-77.

Allmer, Thomas. 2017. Academic Labour, Digital Media and Capitalism. Critical Sociology: 117. doi: $10.1177 / 0896920517735669$

Blackmore, Paul and Kandiko, Camille B. 2011. Motivation in academic life: a prestige economy. Research in Post-Compulsory Education 16 (4): 399-411.

Bourdieu, Pierre. 1984. Homo Academicus. Translated by Peter Collier. Stanford: Stanford University Press.

Braverman, Henry. 1998. Labor and Monopoly Capital. The Degradation of Work in the Twentieth Century. New York: Monthly Review Press.

Caffentzis, George. 2005. Immeasurable Value? An Essay on Marx's Legacy. The Commoner 10: 87-114.

Cámara Izquierdo, Sergio. 2006. A Value-Oriented Distinction Between Productive and Unproductive Labour. Capital \& Class 30 (3): 37-63.

Clark, William. 2006. Academic Charisma and the Origins of the Research University. Chicago: The University of Chicago Press.

Cleaver, Harry. 2000. Reading 'Capital' Politically. Edinburgh: AK Press.

De Angelis, Massimo. 2005. Value(s), Measure(s) and Disciplinary Markets. The Commoner 10: 66-86.

De Angelis, Massimo and David Harvie. 2009. 'Cognitive Capitalism' and the Rat-Race: How Capital Measures Immaterial Labour in British Universities. Historical Materialism 17 (3): 3-30.

Duménil, Gérard and Dominique Lévy. 2011. Unproductive Labor as Profit-Rate-Maximizing Labor. Rethinking Marxism: A Journal of Economics, Culture \& Society 23 (2): 216-225.

Fuchs, Christian. 2018. Universal Alienation, Formal and Real Subsumption of Society under Capital, Ongoing Primitive Accumulation by Dispossession: Reflections on the Marx@200-Contributions by David Harvey and Michael Hardt/Toni Negri. tripleC: Communication, Capitalism \& Critique. Open Access Journal for a Global Sustainable Information Society 16 (2): 454-467.

Fuchs, Christian and Marisol Sandoval. 2013. The Diamond Model of Open Access Publishing: Why Policy Makers, Scholars, Universities, Libraries, Labour Unions and the Publishing World Need to Take Non-Commercial, Non-Profit Open Access Serious. tripleC: Communication, Capitalism \& Critique. Open Access Journal for a Global Sustainable Information Society 13 (2): 428-443.

Godin, Benoît. 2007. From Eugenics to Scientometrics: Galton, Cattell, and Men of Science. Social Studies of Science 37 (5): 691-728.

Gough, Ian. 1972. Marx's Theory of Productive and Unproductive Labour. New Left Review 76: 47-72.

Gulli, Bruno. 2009. Knowledge Production and the Superexploitation of Contingent Academic Labor. Workplace 16: 1-30.

Gulli, Bruno. 2005. Labor of Fire. The Ontology of Labor between Economy and Culture. Philadelphia: Temple University Press.

Hall, Richard. 2018. On the Alienation of Academic Labour and the Possibilities for Mass Intellectuality. tripleC: Communication, Capitalism \& Critique. Open Access Journal for a Global Sustainable Information Society 16 (1): 97-113.

Hardt, Michael and Antonio Negri. 2018a. The Powers of the Exploited and the Social Ontology of Praxis. tripleC: Communication, Capitalism \& Critique. Open Access Journal for a Global Sustainable Information Society 16 (2): 415-423.

Hardt, Michael and Antonio Negri. 2018b. The Multiplicities within Capitalist Rule and the Articulation of Struggles. tripleC: Communication, Capitalism \& Critique. Open Access Journal for a Global Sustainable Information Society 16 (2): 440-448. 
Hardt, Michael, and Antonio Negri. 2009. Commonwealth. Cambridge, MA: Harvard University Press.

Hardt, Michael and Antonio Negri. 2001. Empire. Cambridge, MA: Harvard University Press.

Harney, Stefano and Fred Moten. 1998. Doing academic work. In Chalk Lines: The Politics of Work in the Managed University, edited by Randy Martin, 154-180. Durham, NC: Duke University Press.

Harvey, David. 2018. Universal Alienation and the Real Subsumption of Daily Life under Capital: A Response to Hardt and Negri. tripleC: Communication, Capitalism \& Critique. Open Access Journal for a Global Sustainable Information Society 16 (2): 449-453.

Harvey, David. 2010. A Companion to Marx's Capital. London: Verso.

Harvie, David. 2006. Value Production and Struggle in the Classroom: Teachers Within, Against and Beyond Capital. Capital \& Class 30 (1): 1-32.

Harvie, David. 2005. All Labour Produces Value for Capital and We All Struggle Against Value. The Commoner 10: 132-171.

Hazelkorn, Ellen. 2011. Rankings and the Reshaping of Higher Education. Basingstoke: Palgrave Macmillan.

Hicks, Diana, Paul Wouters, Ludo Waltman, Sarah de Rijcke and Ismael Rafols. 2015. The Leiden Manifesto for Research Metrics. Nature, 22 April, 520: 429-431.

Houston, David. 1997. Productive-Unproductive Labor: Rest in Peace. Review of Radical Political Economics 29 (1): 131-147.

Kicillof, Axel and Guido Starosta. 2007. Value form and Class Struggle: A Critique of the Autonomist Theory of Value. Capital \& Class 31 (2): 13-40.

Laibman, David. 1999. Productive and Unproductive Labor: A Comment. Review of Radical Political Economics 31 (2): 61-73.

Larivière, Vincent, Stefanie Haustein and Philippe Mongeon. 2015. The Oligopoly of Academic Publishers in the Digital Era. PLOS ONE 10 (6): 1-15.

Lebowitz, Michael A. 2003. Beyond Capital. Political Economy of the Working Class. Basingstoke: Palgrave MacMillan.

Luxemburg, Rosa. 2013/1925. Introduction to Political Economy. In The Complete Works of Rosa Luxemburg, Volume 1: Economic Writings 1, edited by Peter Hudis, 89-300. London: Verso.

Mandel, Ernst. 1978. Late Capitalism. London: Verso.

Marginson, Simon. 2016. Higher Education and the Common Good. Melbourne: MUP Academic.

Marginson, Simon. 1998. Value Creation in the Production of Services. A Note on Marx. Cambridge Journal of Economics 22: 573-585.

Marx, Karl. 2000/1977. Theories of Surplus Value: Books I, II and III. New York: Prometheus Books.

Marx, Karl. 1994/1859. A Contribution to the Critique of Political Economy. MECW Vol. 34. London: Lawrence and Wishart.

Marx, Karl. 1982/1867. Capital. A Critique of Political Economy: Volume One. London-New York: Penguin Books and New Left Review.

Marx, Karl. 1981/1894. Capital. A Critique of Political Economy: Volume Three. Harmondsworth: Penguin.

Marx, Karl. 1973/1939. Grundrisse. New York: Random House.

Mazzucato, Mariana. 2013. Entrepreneurial State: Debunking Public vs. Private Sector Myths. London: Anthem Books.

Meiksins, Peter. 1981. Productive and Unproductive Labor and Marx's Theory of Class. Review of Radical Political Economics 13: 32-42.

Mohun, Simon. 2002. Productive and Unproductive Labor: A Reply to Houston and Laibman. Review of Radical Political Economics 34: 203-220.

Mohun, Simon. 1996. Productive and Unproductive Labor in the Labor Theory of Value. Review of Radical Political Economics 24 (4): 30-54. 
Moraitis, Alexis. B. and Jack Copley. 2017. Productive and Unproductive Labour and Social Form: Putting Class Struggle in its Place. Capital \& Class 41 (1): 91-114.

Münch, Richard. 2014. Academic Capitalism. Universities in the Global Struggle for Excellence. London: Routledge.

Neave, Guy. 2012. The Evaluative State, Institutional Autonomy and Re-engineering Higher Education in Western Europe: The Prince and His Pleasure. Basingstoke: Palgrave.

Negri, Antonio. 2014. „Praca Produkcyjna i Nieprodukcyjna”. In LUM, Marks. Nowe Perspektywy. Warszawa: Wydawnictwo Naukowe PWN.

Neylon, Tyler. 2012. The Cost of Knowledge [website]. Accessed April 22, 2019. http://thecostofknowledge.com/

Pasquinelli, Matteo. 2015. Italian Operaismo and the Information Machine. Theory, Culture Society 32 (3): 49-68.

Pasquinelli, Matteo 2014a. The Number of the Collective Beast: Value in the Age of the New Algorithmic Institutions of Ranking and Rating. Unpublished paper, delivered at the New Industries Conference: Money and Debt in the Post-Industrial World, curated by Inke Arns and Fabian Saavedra-Lara in Dortmund, Germany. Accessed April 24, 2019. http://matteopasquinelli.com/number-of-the-collective-beast/

Pasquinelli, Matteo. 2014b. The Labour of Abstraction: Seven Transitional Theses on Marxism and Accelerationism. Fillip Magazine 19: n.p. Accessed April 24, 2019. http://fillip.ca/content/the-labour-of-abstraction

Pasquinelli, Matteo. 2011. Machinic Capitalism and Network Surplus Value: Notes on the Political Economy of the Turing Machine. Unpublished paper, delivered at the Joy Forever. Political Economy of Social Creativity Conference in Warsaw. Accessed April 26, 2019. https://bit.ly/2Dui9AH

Pasquinelli, Matteo. 2009. Google's PageRank Algorithm: A Diagram of Cognitive Capitalism and the Rentier of the Common Intellect. In Deep Search: The Politics of Search beyond Google, edited by Konrad Becker and Filip Stalder, 152-162. London: Transaction Publishers.

Peekhaus, Wilhelm. 2012. The Enclosure and Alienation of Academic Publishing: Lessons for the Professoriate. tripleC: Communication, Capitalism \& Critique. Open Access Journal for a Global Sustainable Information Society 10 (2): 577-599.

Pitts, Frederick H. 2015. Creative Industries, Value Theory, and Michael Heinrich's New Reading of Marx. tripleC: Communication, Capitalism \& Critique. Open Access Journal for a Global Sustainable Information Society 13 (1): 192-222.

Ratajczak, Mikołaj. 2015. Divine Management of Worldly Matters: Agamben's Theological Genealogy of Economy as a Political Philosophy of Praxis. Praktyka Teoretyczna 3 (17): 75-105.

Roberts, Bruce. 2014. Productive/Unproductive: Conceptual Topology. Rethinking Marxism: A Journal of Economics, Culture \& Society, 26 (3): 336-359.

Robinson, Bruce. 2014. With a Different Marx: Value and the Contradictions of Web 2.0 Capitalism. The Information Society 31 (1): 44-51.

Roggero Gigi. 2011. The Production of Living Knowledge. Philadelphia: Temple University Press.

Rubin, Isaak. 1990. Essays on Marx's Theory of Value. Montreal: Black Rose Books.

Shore, Chris and Susan Wright. 2015. Audit Culture Revisited: Rankings, Ratings, and the Reassembling of Society. Current Anthropology 56 (3): 421-444.

Storbeck, Olaf. 2012. Teure Wissenschaft: Forscher boykottieren Fachverlag. Handelsblatt, 14 February. Accessed April 24, 2019. https://www.handelsblatt.com/politik/konjunktur/oekonomie/nachrichten/teurewissenschaft-forscher-boykottieren-fachverlag/6203330.html

Savran, Sungur and Ahmet E. Tonak. 1999. Productive and Unproductive Labour: An Attempt at Clarification and Classification. Capital \& Class 23 (2): 113-52. 
Szadkowski, Krystian. 2016a. Towards an Orthodox Marxian Reading of Subsumption(s) of Academic Labour under Capital. Workplace: A Journal for Academic Labor 28: 9-29.

Szadkowski, Krystian. 2016b. Socially Necessary Impact/Time: Notes on the Acceleration of Academic Labor, Metrics and the Transnational Association of Capitals. Teorie Vědy/Theory of Science, 38 (1): 53-85.

Vercellone, Carlo. 2007. From Formal Subsumption to General Intellect: Elements for a Marxist Reading of the Thesis of Cognitive Capitalism. Historical Materialism 15: 13-36.

Vostal, Flip. 2016. Accelerating Academia. The Changing Structure of Academic Time. Basingstoke: Palgrave.

Ware, Mark and Michael Mabe. 2015. The STM Report: An Overview of Scientific and Scholarly Journal Publishing. The Hague: International Association of Scientific, Technical and Medical Publishers. Accessed April 26, 2019. https://bit.ly/2L88Oom

Wilsdon, James, Liz Allen, Eleonora Belfiore, Philip Campbell, Stephen Curry et al. 2015. The Metric Tide: Report of the Independent Review of the Role of Metrics in Research Assessment and Management. London: HEFCE. doi: 10.13140/RG.2.1.4929.1363

Woodcock, Jamie. 2018. Digital Labour in the University: Understanding the Transformations of Academic Work in the UK. tripleC: Communication, Capitalism \& Critique. Open Access Journal for a Global Sustainable Information Society 16 (1): 129-142.

\section{About the Author}

\section{Krystian Szadkowski}

Krystian Szadkowski is a researcher at the UNESCO Chair for Institutional Research and Higher Education Policy of Adam Mickiewicz University in Poznań, Poland. His interests cover Marxist political economy and transformations of higher education systems in Central Eastern Europe, as well as the issues of the public and the common in higher education. He worked as a researcher for Education International (Brussels, Belgium). He collaborates with the Centre for Global Higher Education, Institute of Education, University College London. 